\title{
The Role of Refusal Instruction in Pragmatic Development
}

\author{
Farahman Farrokhi \\ English department, University of Tabriz \\ E-mail: ffarrokhi20@yahoo.co.uk \\ Soheil Atashian (Corresponding author) \\ MA Student in TEFL, University of Tabriz, Tabriz, Iran \\ Tel: 98-914-3000-367Ｅ-mail: soheil.atashian@yahoo.com
}

Received: July 30, 2012

Accepted: August 13, 2012

Published: August 25, 2012

doi:10.5430/wje.v2n4p85

URL: http://dx.doi.org/10.5430/wje.v2n4p85

It is to be noted that this study is based upon the M.A. thesis of the second author to be presented at the University of Tabriz.

\begin{abstract}
This study was set up to further investigate whether either of the instruction types, explicit vs. implicit, proves more efficient in ameliorating pragmatic performance of Iranian EFL learners. The speech act under investigation in this quasi-experimental study was refusal. Sixty Iranian learners of English as a foreign language participated in this study in which they were assigned to three groups of explicit, implicit, and control. All groups were exposed to conversations from 'Spectrum' English books where refusals stood out. In the treatment groups it was intended to raise pragmatic awareness whereas in control group conversations acted as a source of English comprehension and production. The findings appear to prove the efficiency of explicit instruction over implicit one in boosting Iranian EFL learners' pragmatic performance.
\end{abstract}

Keywords: Pragmatic development, Pragmatic instruction, Refusals, Explicit instruction, Implicit instruction

\section{Introduction}

Successful communication in the target language requires not only the knowledge of grammar and vocabulary but also pragmatic competence and knowledge about the culture of target language (Rezvani \& Ozdemir, 2010). As Eslami-Rasekh (2004) puts it, the development of pragmatic and sociolinguistic rules of language use is important for language learners. It is necessary to understand and create language that is appropriate to the situations in which one is functioning, because failure to do so may cause users to miss key points that are being communicated or to have their messages misunderstood. Many studies in recent years have accentuated the crucial role pragmatics plays in second/foreign language learning. However, as Soler (2005) asserts, the significant question of whether pragmatics is teachable, is proposed. Thus, we are almost left with an incomplete picture of the nature of pragmatic instruction.

\section{Literature Review}

First and foremost, as Franklin (2003) et al. indicates, what sheds light on linguistic meaning in context is pragmatics. Taken by itself, the sentence is essentially uninterruptable. Its linguistic meaning is clear however, context plays a far integral role in comprehending the genuine sense of the sentence. How language is used may not warrant a topic on its own, as believed by Kempson (1996). Thus, words convey much more than they mean. Also, Ellis (2008) seems to strongly support the idea that, full understanding of how formal properties are learnt will not be achieved without examining the way in which these properties are used in actual communication.

As Ishihara (2003) points out, use of language is so closely and uniquely tied to the culture and often rules of speaking vary across languages. According to these implicit cultural rules, we constantly alter our language use depending on the situation and on the interlocutor. On the other hand, the constant and fast development of new communication technologies and means of transportation, have increased significantly, people's opportunities for cross-linguistic and cross-cultural interactions. So, as Silva (2000) puts it: 'This global interaction calls our attention to issues of multilingualism, and leads us to questions of pragmatic competence among multilinguals’. (p. 161) 


\subsection{Language Pragmatics}

Some constitute pragmatics as: 'A user-based prospective on the language sciences such as linguistics, the philosophy of language and the sociology of language which essentially focuses on the exploration of language use and the users of language in real-life situations and, more generally, on the principles which govern language in everyday interaction. (Pütz and Neff-Aertselaer, 2008, p. IX). Therefore, pragmatics studies language as realized in interactive contexts and consequently, as the creation of meaning in online discourse situations.

Moreover, to Schauer (2009), pragmatics is a relatively young discipline, compared to, for example, phonetics and syntax which began to establish itself as an independent area of linguistic research only about forty years ago. Linguistic pragmatics has its foundation in language philosophy and developed, he believes, as a result of ideas concerning the functions and use of language. Schauer points out that the first definition of pragmatics that is generally quoted was developed by Morris (1938), who, allegedly, defined pragmatics as 'the study of the relation of signs to interpreters.' (p. 6)

In their book 'investigating Pragmatics in Foreign Language Learning and Testing', Soler and Martinez-Flor (2008) deal profoundly with language pragmatics. To them, the study of pragmatics encompasses areas such as deixis, conversational implicature, presupposition, and conversational structure. However, the study of second language pragmatics, also referred to as interlanguage pragmatics (ILP), focuses mainly on the investigation of speech acts, conversational structure and conversational implicature. Interlanguage pragmatics research, they state, has focused on describing and explaining learners' use, perception and acquisition of second language (L2) pragmatic ability both in L2 and foreign language contexts.

Ishihara and Cohen (2010), two eminent figures in the domain of language pragmatics, have come up with a work entitled 'Teaching and Learning Pragmatics' which contains longitudinal studies and the concomitant findings. It is believed that the notion of pragmatics has numerous meanings depending on the context. When it is said someone is taking a 'pragmatic approach' to something, the implication is that the person is being practical. Yet, the word assumes a more specialized meaning in applied linguistics. The term pragmatic ability refers both to knowledge about pragmatics and the ability to use it.

In a comprehensive study, Chang (2009) advocates the significance of pragmatics asserting that to use language accurately, mastery of the formal properties of phonological, lexical and grammatical systems is required. The accuracy of language form, however, does not guarantee the appropriateness of the language use. Learners, he keeps, need to acquire competence as to when to speak, and what to talk about with whom, where and in what manner in order to use language appropriately.

McLean (2004) believes that taking pragmatics into account would give students a fighting chance, stating that, by attending to pragmatic factors in second language situations, students will be better able to make informed choices in negotiating effective communication. He embedded Thomas's (1995) definition of pragmatics in his study which refers to pragmatics as meaning in interaction. Meaning is not something that is inherent in the words alone. Making meaning, he says, is a dynamic process of negotiation involving both speaker and hearer.

Upon perusing the background studies done in the realm of pragmatics, one cannot ignore the precious status Rosangela Silva. In one study, Silva (2000) related the topics of pragmatics, bilingualism and the native speakers. She makes it overt that there is a bias in second language acquisition literature that a second/foreign language learner does not have 'native speaker competence' in the second/foreign language. Contrary to this view, researchers in bilingualism and multilingualism question the whole notion of 'native-like competence'. Findings from her study demonstrate that monolinguals constantly adjust the way they deal with their L1 in both linguistic and pragmatic terms. Pragmatic aspects of a language seem to be very susceptible to changes, motivated by a mixture of psychological and sociolinguistic factors.

\subsection{Pragmatic Instruction}

All indicated so far is a lucid manifestation of the significance of pragmatics, and the key role it plays in linguistics. However, this issue would culminate as it gains entry within the realm of pedagogy. That is, if the importance of pragmatics is vindicated, the question of how to relate it to the instructional contexts is raised. Following is an incisive delineation of the scholarly works and research conducted, so as to shed light on pragmatic instruction.

In recent years, one of the main concerns of language teachers in the field of second language acquisition was the development of learners' communicative competence in second or foreign language; assert Martinez-Flor and Uso-Juan (2010). Recent models of communicative competence have revealed that communicating appropriately and effectively in a target language requires not only knowledge of the features of the language systems, but also of the pragmatic rules of language use. Given this need, Martinez-Flor and Uso-Juan (2010b) propose what has been decided on by previous 
researchers that the presentation of rich and contextually appropriate input has been regarded as necessary condition for developing learners' pragmatic ability when understanding and performing speech acts in the target language.

Then, Ishihara (2010) presents three terms in teaching pragmatics: noticing, awareness and attention. She indicates that attention and awareness can be viewed as inseparable. Attention is considered as a variety of mechanisms or subsystems that control access to awareness. Attention, she keeps, is limited and selective in nature, managing access to consciousness and leading to the control of action and learning. Ishihara further discussed that when pragmatic information is noticed, whether attended to deliberately or inadvertently, the input has the potential to become intake and maybe stored in long-term memory.

Kondo (2001), on the other hand, proposes an awareness-raising approach towards pragmatic instruction. She revealed that, learners' discussion after they had analyzed their own speech act performance and the data presented in the textbook indicated that learners have come to be aware of several pragmatic aspects related to cross-cultural understanding through instruction.

Takimoto (2009) evaluated the effectiveness of three types: input-based instruction, comprehension-based instruction, structured input-instruction, and conscious-raising instruction on the development or learners' pragmatic proficiency. The results of the data analysis indicate that the three treatment groups performed significantly better than the control group, but that the comprehension-based instruction group did not maintain the positive effects of the treatment between the posttest and follow-up test in the listening test.

\subsection{Refusals}

Many linguists and scholars in the realm of pragmatics, consider refusals a little different from other speech acts since, they occur as a result or response to other speech acts. For instance, Ellis (2008) believes that it is difficult to adapt refusals with Searle's (1975) classification of speech acts. Ellis also points out that refusals occur in the form of responses to a variety of illocutionary acts such as invitations, offers, requests, and suggestions. Ellis proposes that refusals be treated as an informal 'interactional' turn rather than a 'speech act' proper.

Ishihara and Cohen (2010) put that, in making a refusal, the speaker/writer is typically communicating a potentially undesirable message as far as the listener/reader is concerned. There are some strategies employed in mitigating refusals. They assert that refusals are often made in response to speech act of requests, invitations, offers, and suggestions. Refusals can be either direct or indirect. Ishihara and Cohen also reveal that refusals can be accompanied by some other elements such as statement of positive opinion, statement of empathy and so forth.

Kawate-Mierzejewska (2006) examined request-refusal sequences among 20 Japanese speakers of Japanese (JJs), and 20 American English speakers of Japanese (AJs) in a naturalistic context. All request-refusal situations were through telephone conversations. As a result, the AJs utilized seven different types of refusal sequences, consisting of 13 different refusal sub-sequences, while The JJs used 6 different types consisting of seven different refusal sub-sequences.

Kondo (2001), similarly, seeks to find out the effects on pragmatic development through awareness-raising instruction. She considers pragmatic development as the usage of refusals by Japanese EFL learners. Kondo comes to the very conclusion that pragmatics can be taught and, in this case, consciousness-raising is of integral importance for the learners to become aware of the similarities and differences between their native language and the target language. Most importantly, the study revealed that learners' choices of refusal strategies changed and became more similar to American pattern after explicit instruction.

Umale (2011) investigated pragmatic failure in refusal strategies and contrasted British versus Omani interlocutors. The refusals under study in this research were in response to requests. She defines refusals as 'a face-threatening act that tends to disrupts harmony in relationship' (p. 18). Umale analyzed the amount of direct and indirect strategies employed by subjects to refuse. In the case of direct strategies, Omanis used more direct strategies than the British. Indirect strategies in this study are reason and expressing regret. The Omanis and the British both used reason but less than expressing regret.

In a similar study, Turnbull (2001) focuses on the appropriateness of pragmatic elicitation techniques for generating talk to be used in analyses of talk and social structure. He takes the case of request refusals. To him, the best pragmatic elicitation techniques are the ones in which (I) data are generated in situations in which researchers can manipulate variables in the testing of hypotheses, and (II) speaker can talk freely and spontaneously without awareness that their talk is the object of study. This claim was tested in this study, and it was concluded that an experimental technique is the preferred pragmatic elicitation technique.

In a study entitled 'how to say no', Chang (2009) tries to investigate pragmatic transfer in refusals by native speakers of 
Mandarin speaking English, and to what extent transfer is influenced by the learners' level of L2 proficiency. She analyzed responses in terms of (1) the frequency of semantic formulas, and (2) the content of semantic formulas. It was found that while all groups, including 35 American college students, 41 English-major seniors, 40 English-major freshmen, and 40 Chinese-major sophomores, employed a similar range of semantic formula in responding to the refusals elicited by different initiating acts, though they differed in the frequency and content of the semantic formulas.

Allami and Naeimi (2010) conducted a cross-linguistic study of refusals upon an analysis of pragmatic competence development in Iranian EFL learners. They further indented to explore the frequency, shift and content of semantic formulas with regard to learners' language proficiency, status of interlocutors and types of eliciting acts. Findings revealed that these were differences in the frequency, shift and content of semantic formulas used in refusals by Iranian and American speakers when responding to a higher, an equal, and a lower-status person. On the other hand, native speakers of Persian displayed a nearly high level of frequency shift in their use of several semantic formulas, whereas American patterns for refusals were quite consistent regardless of status level.

A study aimed at investigating expressing refusals in Korean and in American English was conducted by Kwon (2004). Results of this work indicated that although a similar range of refusal strategies were available to the two language groups, cross-cultural variation was evident in the frequency and content of semantic formulas used by each language group in relation to the contextual variables, which include the status of interlocutors and eliciting acts. Korean speakers, for instance, hesitated more frequently and used direct refusal formulas much less frequently than did English speakers. In addition, Korean speakers frequently paused and apologized before refusing.

\section{Method}

\subsection{Research Questions and Hypotheses}

RQ: What are the similarities and differences between explicit and implicit instruction of refusals in improving pragmatic performance of Iranian EFL learners?

H0: Explicit and implicit instructions of refusals improve the pragmatic production of the learners to the same extent.

H1: Explicit instruction benefits learners' pragmatic performance of refusals more than implicit instruction.

H2: Implicit instruction benefits learners' pragmatic performance of refusals more than explicit instruction.

\subsection{Subjects}

Sixty upper-intermediate EFL learners, 30 female and 30 male all between 19 to 25 years of age, at a language institute in Tabriz, Iran, were selected to participate in the study. Prior to the initiation of the study, some measures and steps were taken to assure various factors contributing to valid and reliable results. First of all, for the sake of homogeneity, their proficiency level in the English language was measured by a compilation of existing sample TOEFL tests. Further, an ethnic monitoring questionnaire revealed that no significant difference existed among subjects in terms of ethnicity and academic background. Then, through a stratified randomization, 60 subjects were assigned to control and treatment groups, 20 each. So, three groups, i.e. explicit, implicit and control were formed. Each group included 10 female and 10 male subjects.

\subsection{Procedures}

A pretest/posttest design was adopted in this study. After having formed the three groups under investigation, I measured all subjects' pragmatic performance of L2 refusals through Discourse Completion Tests, DCTs (See Appendix). Due to the fact that this study did not take a contrastive approach and neither did it intend to investigate the strategies learners employ in the case of speech acts, DCTs are in target language, English.

This study was implemented in an institutional context at Kish Institute of Science and Technology in Tabriz, Iran. Subjects in all groups were in their first phase of upper-intermediate course, meeting three times a week. Each class session took two hours. All the subjects in the experimental groups received treatment throughout a term which lasted 42 hours. The course book employed at that institute was 'Total English' series. In addition to the main class material, all the subjects in the three groups of explicit, implicit and control were exposed to dialogs of 'Spectrum' English book in which refusals were embedded.

By exposing the subjects to the dialogs in two treatment groups, i.e. explicit and implicit, it was intended to raise learners' pragmatic awareness of L2 refusals. In the control group, on the other hand, mere improvement of English proficiency in terms of comprehension and production was sought. In the explicit group, a focus on forms instruction was provided based on explicit awareness-raising tasks on refusals. That is, sentence structures were elaborated upon for the learners to deduce refusal forms. However, in the implicit group, the input enhancement approach was taken on pragmalinguistic and sociolinguistic factors involved in refusals. This means that in implicit group the setting was organized in a way that learners' induced refusal forms from the dialogs. 


\section{Results}

At the end of the treatment period, a posttest with the format of an open-ended Discourse Completion Test (the same as the pretest) was administered in all the three groups under investigation. Situations of DCT in which subjects were to refuse something, were of the same theme but different occasions so as to account for the practice effect. An American and an Australian, both native speakers of English, reached an agreement on ranking each subject's performance in pretest/posttest papers.

Each sheet of pretest and posttest was rated on a five-scale ranking order: 5 (excellent), 4 (very good), 3 (good), 2 (average), 1 (poor). Both of the native speakers of English, who held academic degrees in various fields, were asked to rate each pretest and posttest DCT without having been presented with the distinctions of the three groups under study. Then with the assistance of a statistician, the results were analyzed employing positive rank test statistics and Wilcoxon Signed Ranks Test.

Data gained from the pretest and posttest for each of the three groups, were processed through Statistical Package for the Social Sciences (SPSS) computer program. The results of the data processing from the pretest and posttest in control, explicit and implicit group are presented in tables 1, 2 and 3 respectively. Table 1 reports on the subjects in control group. It is obvious from the cumulative percent in pretest and posttest that in control group, where the presentation of dialogs was merely to ameliorate English proficiency of the subjects, no significant change occurs in pragmatic production of refusals.

$<$ Table 1 about here $>$

In Tables 2 and 3, on the other hand, the effect of instruction on pragmatic production of refusals is quite tangible. Particularly, in explicit group there is a drastic change in subjects' performance of refusals after the treatment period.

$<$ Tables 2 and 3 about here $>$

Table 4 is the calculation of all the data processing formulas for the three groups under study. To make the concomitant statistical results more vivid, it is to put that $\mathrm{p}$-value is the probability of obtaining a test statistics. If $\mathrm{p}$-value is smaller than $\alpha(\mathrm{p}<0.05)$, it means that the difference is significant. That is to say, if $\mathrm{p}$-value is .000 , the null hypothesis is rejected. As illustrated by table 4, the P-value (Exact Sig. 2-tailed) for control, explicit and implicit groups is 1.000, .000, and .013 respectively. This is indicative of the fact that, instruction does make a difference in developing pragmatic performance of EFL learners. Further, it is evident from table 4 that subjects in the explicit group surpassed those in implicit group in pragmatic performance.

$<$ Table 4 about here $>$

\section{Discussion and Conclusions}

All in all, the findings of this research on pragmatics are indicative of the fact that instruction seems to make a tangible difference in improving L2 learners' pragmatic production of refusals. However, explicit instruction proves more effective in boosting pragmatic ability of L2 learners. As a result, $\mathrm{H} 0$ of this study which had not foreseen any difference between explicit and implicit instruction on pragmatic development, is rejected. Previous studies on the effects of instruction on pragmatic performance go in the same line.

In Iranian EFL context, it is safe to claim that due to the lack of direct communication of Iranian EFL learners with native speakers of English, pragmatics proves even more crucial. Studies and observations in Iranian context have pointed out that EFL learners produce language which is almost structurally accurate but not contextually appropriate. Given that appropriate use of language is the case of L2 pragmatics, it is recommended that language teachers be aware of this need in learners. More specifically, explicit approach of teaching speech acts turns out to be more efficient in learners' pragmatic development.

\section{Pedagogical Implications}

This study contributes to the previous research on the positive effect of instruction on the development of pragmatic competence in Second and foreign language learning. So, language teachers should take this fact into consideration to include issues of language pragmatics in ESL/EFL classes. Similarly, it is on pedagogy scholars and syllabus planners not to ignore knowledge of pragmatic aspects in their syllabus design. 


\section{References}

Alcon Soler, E. \& Martinez-Flor, A. (2008). Investigating Pragmatics in Foreign Language Learning, Teaching and Testing. Great Britain: Cromwell Press, (Chapter 1).

Alcon Soler, E., (2005). Does Instruction Work for Learning Pragmatics in the EFL Context?. System. 33. 417-435. http://dx.doi.org/10.1016/j.system.2005.06.005

Allami, H. Naeimi, A. (2011). A Cross-linguistic Study of Refusals: An Analysis of Pragmatic Competence Development in Iranian EFL Learners. Journal of Pragmatics. 43. 385-406. http://dx.doi.org/10.1016/j.pragma.2010.07.010

Chang, Y. (2009). How to Say No: An Analysis of Cross-cultural Difference and Pragmatic Transfer. Language Sciences. 31. 477-493. http://dx.doi.org/10.1016/j.langsci.2008.01.002

Ellis, R., (2008). The Study of Second Language Acquisition. Oxford University Press.

Eslami-Rasekh, Z., (2004). Learning the Pragmatic Awareness of Language Learners. ELT Journal. 59(3). 199 -208. http://dx.doi.org/10.1093/elt/cci039

Fromkin, V., Rodman R. \& Hymas, N. (2003). An Introduction to Language. United States: Thomson, (Chapter 5).

Ishihara, N. \& A. Cohen, (2010). Teaching and Learning Pragmatics. Longman: Pearson.

Ishihara, N., (2003). Identity and Pragmatic Performance of Second Language Learners. Paper Presented at the Annual Conference of the American Association for Applied Linguistics.

Kawate-Mierzejewska, M. (2006). Request-refusal Interactions in Telephone Conversations. Tokyo: Kuroshio Publishers.

Kempson, R. M. (1996). Semantics, Pragmatics and Natural-Language interpretation. Blackwell.

Kondo, S. (2001). Instructional Effects on Pragmatic Development: Refusal by Japanese EFL Learners. Publications of Akenohoshi Women's Junior College. 19. 33-51.

Kwon, J. (2004). Expressing Refusals in Korean and in American English. Multilingua. 23. 339-364. http://dx.doi.org/10.1515/mult.2004.23.4.339

Martinez-Flor, A. \& E. Uso-Juan, (2010a). Pragmatics and Speech Act Performance. Amsterdam: John Benjamins.

Martinez-Flor, A. \& E. Uso-Juan, (2010b). Speech Act Performance: Theoretical, Empirical and Methodological Issues. Amsterdam: John Benjamins.

McLean, T. (2004). Giving Students a Fighting Chance: Pragmatics in the Language Classroom. TESL Canada Journal. 21(2). 72-92.

Morris, C. H. (1938). Foundation of the Theory of Signs. Chicago: University of Chicago Press.

Ozdemir, C. Rezvani S. A. (2010). Interlanguage Pragmatics in Action: Use of Expressions of Gratitude. Procedia Social and Behavioral Sciences. 3. 194-202. http://dx.doi.org/10.1016/j.sbspro.2010.07.032

Pütz, M. \& Aertselaer, J. (2008). Developing Contrastive Pragmatics. Berlin: Sigurd Wendland.

Searle, J. (1975). Indirect Speech Acts in P. Cole and J. Morgan. New York: Academic Press.

Silva, R. (2000). Pragmatics, Bilingualism, and the Native Speaker. Language and Communication. 20. 161-178. http://dx.doi.org/10.1016/S0271-5309(99)00019-1

Schauer, G. (2009). Interlanguage Pragmatic Development. New York: Continuum, (Chapter 2).

Takimoto, M. (2009). Exploring the Effects of Input-based Treatment and Test on the Development of Learners' Pragmatic Proficiency. Journal of Pragmatics. 41. 1029-1046. http://dx.doi.org/10.1016/j.pragma.2008.12.001

Thomas, J. (1995). Meaning in "interaction: An Introduction to Pragmatics. New York: Longman Group.

Turnbull, W. (2001). An Appraisal of Pragmatic Elicitation Techniques for the Social Psychological Study of Talk: The Case of Request Refusals. Pragmatics. 11(1). 31-61.

Umale, J. (2011). Pragmatic Failure in Refusal Strategies: British versus Omani Interlocutors. Arab World English Journal. 2(1). 18-46. 
Table 1. Control Group

\begin{tabular}{|l|l|l|l|l|l|l|l|l|l|}
\hline$\underline{\text { Pretest }}$ & Frequency & Percent & $\begin{array}{l}\text { Valid } \\
\text { Percent }\end{array}$ & $\begin{array}{l}\text { Cumulative } \\
\text { Percent }\end{array}$ & $\underline{\underline{\text { Posttest }}}$ & Frequency & Percent & $\begin{array}{l}\text { Valid } \\
\text { Percent }\end{array}$ & $\begin{array}{l}\text { Cumulative } \\
\text { Percent }\end{array}$ \\
\hline Valid & 2 & 10.0 & 10.0 & 10.0 & Valid 1 & 1 & 5.0 & 5.0 & 5.0 \\
1 & 7 & 35.0 & 35.0 & 45.0 & & 7 & 35.0 & 35.0 & 40.0 \\
2 & 10 & 50.0 & 50.0 & 95.0 & 2 & 12 & 60.0 & 60.0 & 100.0 \\
3 & 1 & 5.0 & 5.0 & 100.0 & & 20 & 100.0 & 100.0 & \\
4 & 20 & 100.0 & 100.0 & & 3 & & & & \\
Total & & & & & Total & & & & \\
\hline
\end{tabular}

Table 2. Explicit Group

\begin{tabular}{|c|c|c|c|c|c|c|c|c|c|}
\hline$\underline{\text { Pretest }}$ & Frequency & Percent & $\begin{array}{l}\text { Valid } \\
\text { Percent }\end{array}$ & $\begin{array}{l}\text { Cumulative } \\
\text { Percent }\end{array}$ & Posttest & Frequency & Percent & $\begin{array}{l}\text { Valid } \\
\text { Percent }\end{array}$ & $\begin{array}{l}\text { Cumulative } \\
\text { Percent }\end{array}$ \\
\hline Valid 1 & 1 & 5.0 & 5.0 & 5.0 & Valid 2 & 1 & 5.0 & 5.0 & 5.0 \\
\hline & 8 & 40.0 & 40.0 & 45.0 & & 3 & 15.0 & 15.0 & 20.0 \\
\hline 2 & 10 & 50.0 & 50.0 & 95.0 & 3 & 11 & 55.0 & 55.0 & 75.0 \\
\hline 3 & 1 & 5.0 & 5.0 & 100.0 & 4 & 5 & 25.0 & 25.0 & 100.0 \\
\hline & 20 & 100.0 & 100.0 & & & 20 & 100.0 & 100.0 & \\
\hline 4 & & & & & 5 & & & & \\
\hline Total & & & & & Total & & & & \\
\hline
\end{tabular}

Table 3. Implicit Group

\begin{tabular}{|c|c|c|c|c|c|c|c|c|c|}
\hline Pretest & Frequency & Percent & $\begin{array}{l}\text { Valid } \\
\text { Percent }\end{array}$ & $\begin{array}{l}\text { Cumulative } \\
\text { Percent }\end{array}$ & Posttest & Frequency & Percent & $\begin{array}{l}\text { Valid } \\
\text { Percent }\end{array}$ & $\begin{array}{l}\text { Cumulative } \\
\text { Percent }\end{array}$ \\
\hline \multirow[t]{2}{*}{ Valid 2} & 7 & 35.0 & 35.0 & 35.0 & Valid 2 & 4 & 20.0 & 20.0 & 20.0 \\
\hline & 11 & 55.0 & 55.0 & 90.0 & & 8 & 40.0 & 40.0 & 60.0 \\
\hline \multirow[t]{2}{*}{3} & 2 & 10.0 & 10.0 & 100.0 & 3 & 7 & 35.0 & 35.0 & 95.0 \\
\hline & 20 & 100.0 & 100.0 & & 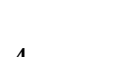 & 1 & 5.0 & 5.0 & 100.0 \\
\hline 4 & & & & & 4 & 20 & 100.0 & 100.0 & \\
\hline \multirow[t]{2}{*}{ Total } & & & & & 5 & & & & \\
\hline & & & & & Total & & & & \\
\hline
\end{tabular}


Table 4. Summary of the results of all three groups

\begin{tabular}{|l|l|l|l|}
\hline & \multicolumn{1}{|c|}{$\begin{array}{c}\text { Control } \\
\text { Pretest-Posttest }\end{array}$} & $\begin{array}{c}\text { Explicit } \\
\text { Pretest-Posttest }\end{array}$ & $\begin{array}{c}\text { Implicit } \\
\text { Pretest-Posttest }\end{array}$ \\
\hline $\mathrm{Z}$ & $-.378^{\mathrm{a}}$ & $-3.464^{\mathrm{a}}$ & $-2.673^{\mathrm{a}}$ \\
Asymp. Sig. (2-tailed) & .705 & .001 & .008 \\
Exact Sig. (2-tailed) & 1.000 & .000 & .013 \\
Exact Sig. (1-tailed) & .500 & .000 & .006 \\
Point Probability & .273 & .000 & .006 \\
& & & \\
\hline
\end{tabular}

a. Based on positive ranks

\section{Appendix: Sample DCT}

1. You are working in a college. You are unmarried and one of your married colleagues who has a big family comes to your house to borrow money.

Colleague: I have a big family and I just don't know where the money goes. The children always need something or the other. Could you lend me $\$ 100$ for a month?

You:

Colleague: It's O.K. I'll borrow from someone else.

2. You are working in a college. Your boss who is the head of your department requests you to come at the weekend to help him.

Boss: If you do not mind, I would like you to come during the weekend to help me with the library work?

You:

Boss: Well, then maybe next weekend.

3. You are a clerk in the Insurance office. You have some important personal work. You request your boss to let you go in the afternoon when the boss is having a lot of pending work for you.

Clerk: I have some important work. Could I leave my office early today?

You:

Clerk: Then, could I leave tomorrow?

4. Your friend invites you on telephone, for dinner and a magic show at a hotel.

Friend: We have arranged a get-together at Radissons. There would be dinner and magic show for children. You are invited to join us.

You:

Friend: Well, I can understand your position.

5. You have joined a company recently and your boss invites you for lunch at his place.

Boss: How about your coming over to lunch tomorrow at my residence?

You:

Boss: Oh, I understand. That is more important. 
6. You are the boss of a company. Your employee wants to invite you for his daughter's birthday.

Employee: I've arranged a small party for my daughter's birthday at home on Monday and I would be delighted if you could come along.

You:

Employee: It's O.K. I can understand.

7. You work as a lecturer in a college. The workload is very high and you are getting stressed over your job. Your friend suggests that you take a break and go to Malaysia.

Friend: You are overstressed due to work. Why don't you take a break and go to Malaysia?

You:

Friend: You could still think about it, later on.

8. You are a student and an excellent football player. You want to become a scientist but your counsellor suggests you to take up football as your career.

Counselor: John, you are so good at football, why don't you make it your career?

You:

Counselor: Well, it is your choice mine was just a suggestion.

9. You are in a new place waiting for your friend, James to pick you up. You have to meet an important person to discuss business prospects. You are hard pressed for time and your friend is going to help you with the transport. It's been an hour and he hasn't shown up. You telephone him and he is not at home and his housekeeper suggests that you take a cab and come home.

Housekeeper: Normally James is very punctual. It seems he has got stuck somewhere. You could take a cab and come home.

You:

House Keeper: Well, if you do not want to, just let me have your name and address.

10. You are a businessman and have no time as you have just started your business. Your son has been a nuisance in the school. The principal wants to meet you in this connection. You generally do all your work yourself and do not take the help of others. Your friend offers to meet the Principal on your behalf and sort out matters.

Friend: If you do not have time, I can go and sort out matters with the Principal.

You: 